Santiago Alexander Guamán-Rivera; Walter Efraín Castro-Guamán; Raúl Lorenzo González-Marcillo; Angela Edith Guerrero-Pincay

http://dx.doi.org/10.35381/r.k.v5i9.625

\title{
Study of the Outbreaks of Bovine Rabies Occurrence in Orellana, Ecuador, period 2012-2018
}

Estudio de los brotes de rabia bovina en Orellana, Ecuador, período 2012-2018

\author{
Santiago Alexander Guamán-Rivera \\ santiagoalexander.guaman@e-campus.uab.cat \\ Universidad Autónoma de Barcelona, Barcelona \\ España \\ https://orcid.org/0000-0001-8699-0655 \\ Walter Efraín Castro-Guamán \\ waltercastromvz@hotmail.com \\ Escuela Superior Politécnica de Chimborazo, Riobamba \\ Ecuador \\ https://orcid.org/0000-0003-1023-329X \\ Raúl Lorenzo González-Marcillo \\ r.gonzalez@espoch.edu.ec \\ Escuela Superior Politécnica de Chimborazo, Riobamba \\ Ecuador \\ https://orcid.org/0000-0002-4653-6076 \\ Ángela Edith Guerrero-Pincay \\ a.guerrero@espoch.edu.ec \\ Escuela Superior Politécnica de Chimborazo, Riobamba \\ Ecuador \\ https://orcid.org/0000-0002-1028-4428
}

Recibido: 1 de mayo de 2020

Revisado: 15 de mayo de 2020

Aprobado: 25 de mayo de 2020

Publicado: 1 de junio de 2020 
Santiago Alexander Guamán-Rivera; Walter Efraín Castro-Guamán; Raúl Lorenzo González-Marcillo; Angela Edith Guerrero-Pincay

\begin{abstract}
In Ecuador, a government institution is responsible to apply regulations for rabies official animal control and reduce it to non-dangerous levels. However, in Orellana, no documented bibliography serves as a resource to assess risk. An observational study of the bovine rabies outbreaks occurrences was carried out from 2012 to 2018 period. With the SAS statistical package, descriptive statistics were obtained; as well as interquartile values of the cases presented for, later, building an endemic channel and showing accumulated prevalence rate each year. The results indicated that a total of 44 cases were presented during all period of study. Finally, we can tell that the frequency of the disease did not show marked seasonality due to climatic factors.
\end{abstract}

Descriptors: Bovine rabies; zoonotic diseases; epidemics. (Words taken from the multilingual Thesaurus AGROVOC)

\title{
RESUMEN
}

En el Ecuador, una institución gubernamental se encarga de aplicar los reglamentos para el control oficial de la rabia y de reducirla a niveles no peligrosos. Sin embargo, en Orellana, no hay ninguna bibliografía documentada que sirva como recurso para evaluar el riesgo. Se realizó un estudio de observación de los brotes de rabia bovina ocurridos en el período de 2012 a 2018. Con el paquete estadístico SAS se obtuvieron estadísticas descriptivas, así como valores intercuartiles de los casos presentados para luego construir un canal endémico y mostrar la tasa de prevalencia acumulada para cada año. Los resultados indicaron que se presentaron un total de 44 casos de rabia durante todo el período de estudio. Por último, podemos decir que la frecuencia de la enfermedad no mostró una marcada estacionalidad debido a factores climáticos.

Descriptores: Rabia bovina; zoonosis; epidemia. (Palabras tomadas del Tesauro multilinguístico AGROVOC).

\section{INTRODUCCION}

Any disease or infection that is naturally transmissible from vertebrate animals to humans and vice versa is classified as zoonoses (Calderon et al., 2018; Patel \& Saxena, 2019). Rabies is one of the most important zoonosis in the world with a high impact on public health. It is an acute disease that affects the central nervous system, causing 
Santiago Alexander Guamán-Rivera; Walter Efraín Castro-Guamán; Raúl Lorenzo González-Marcillo; Angela Edith Guerrero-Pincay

encephalomyelitis, with a case of fatality rate of nearly $100 \%$ (Rocha et al., 2017). It occurs in two different epidemiological patterns: urban rabies with the domestic dog as the main reservoir and transmitter, and sylvatic or rural rabies with different wildlife species acting as reservoirs and/or transmitters (Heinemann et al., 2002). Furthermore, it belongs to RNA viruses of the Rhabdoviridae family and the Lyssavirus genus. All mammals are susceptible to rabies virus infection (King \& Turner, 1993; Heinemann et al., 2002; Rupprecht et al., 2002; Johnson et al., 2014 )

Since the introduction of domestic livestock into the new world, vampire-bat transmitted rabies has been the primary disease problem in livestock (Lee et al., 2012). In cattle, it is an acute disease, invariably fatal, transmitted through the saliva of the vampire bat $D$. rotundus (Anderson et al., 2014; Mello et al., 2019). Hematphhagus bats are found only in Latin America, comprising of three species: Desmodus rotundus, Diphylla eucaudata, and Diaemus younguii (Braga et al., 2014). Moreover, Desmodus rotundus is a major public health concern in subtropical and tropical areas of Latin America (Rupprecht et al., 2002; Belotto et al., 2005). According to the World Health Organization (WHO, 2013), it is also the most abundant hematophagous bat species and is responsible not only for maintaining an antigenic variant of the rabies virus-specific for hematophagous bat (AgV3), but also to transmit it to other bat species (including non- hematophagous) (Braga et al., 2014).

Fatal cases of human rabies transmitted by hematophagous bats reached new heights in Latin America in 2004 (46 cases) and 2005 (55 cases) (WHO, 2013). Most cases occurred in the Amazon region of Brazil and Peru and some remote communities of Colombia (Valderrama et al., 2006; Veloso et al., 2011). In Ecuador, there has been three important sylvatic rabies breakouts in the last 15 years. The first one occurred in 1997 when eight human deaths by rabies were confirmed in the Numbat-Kaime and Akunkuki communities, located in Morona Santiago province. The second outbreak caused four deaths in 2005 in the Jatun Molino, Pastaza province. The last breakout of sylvatic rabies occurred in 2011 in Morona Santiago, which is within Wampuik, Tarimiat, and Tsurik Nuevo 
Santiago Alexander Guamán-Rivera; Walter Efraín Castro-Guamán; Raúl Lorenzo González-Marcillo; Angela Edith Guerrero-Pincay

communities resulting in 11 deaths, including 9 children under the age of 15 (Ortiz-Prado et al., 2015). In this case, the transmission was alluded to vampire bats (D. rotundus). Those mentioned with those cases shared the same conditioning factors, which we divide into two interrelated groups: biological and nonbiological (WHO, 2013). Biological include the presence of vampire bats, the existence of adequate shelter for them, the availability of food sources, and the presence of rabies virus in the area. On the other hand, no biological factors include the type of human productive process and changing patterns in such activities, working and living conditions, access to rabies prophylaxis, and measures being implemented to control bat populations.

Specifically, based on the agreement with the constitution in Ecuador, the article 2 statute of animal health and obligatory character involves the battle against infectious-contagious diseases, endo-ectoparasitic cattle, and fowl (National Assembly of Ecuador, 2017). This legal basis was established as one of the plans of control and prevention of bovine rabies, whose axes are; epidemiological surveillance and diagnosis, vaccination, vector control, and authorized sanitary sensors.

The study of an outbreak of diseases during middle term allows us to know the presence of a certain disease on a population at a given time. Additionally, one of its advantages is low cost and it provides information on the prevalence (Bellido, 2016). Also, the sample used is based on the event of interest, and it investigates the past and the presence of a specific exhibition (Cerda et al., 2013).

The aim of this work is tried to explain the occurrence and behaviour of the outbreaks bovine rabies happened during the years 2012 to 2018 in this Amazon region specifically in Orellana. 
Santiago Alexander Guamán-Rivera; Walter Efraín Castro-Guamán; Raúl Lorenzo González-Marcillo; Angela Edith Guerrero-Pincay

\section{MATERIALS AND METHODS}

\section{Study Location}

The province of Orellana, located in the north of the Ecuadorian Amazon, it is distributed in four cantons (districts); Francisco de Orellana, Loreto, Joya de los Sachas, and Aguarico (San Sebastián at al., 2007). It covers an area of approximately $21.703 \mathrm{~km} 2$ and is located $300 \mathrm{~m}$ above sea level (GADPO, 2015). The climate of the region is characterized with humid tropical rainforest with an average rainfall of $2942 \mathrm{~mm}$ and an

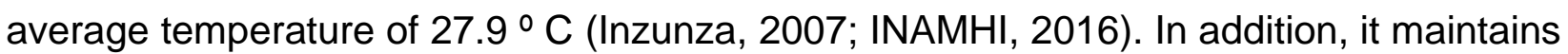
a relative humidity that is almost constant i.e., $80 \%$ year-round (San Sebastián et al., 2007).

Productive Characteristic of the study location

Based on the last population and housing census conducted in 2010, 136.396 people was estimated in Orellana; 64.266 are women and 72.130 correspond to men (INEC, 2010). According to (Ríos et al., 2016), there are 623.825 hectares of which the agriculture sector covers $39.86 \%$ distributed as follows: $31 \%$ permanent crops, $15 \%$ and $48 \%$ cultivated pastures, and 6\% natural pastures (Marcillo, 2018). These dynamics of land use in Ecuadorian amazon is derived from the convergence of different types of livestock systems, being decisive for the use of land under different levels of technology. In 2012, based on information (GADPO, 2015), there was a bovine population of 35.942 animals. However, in the 2015-2019 land planning and development plan, for the year 2013, describes the existence of 44.567 cattle. For 2016, the (MAGAP, 2019), reports 38.398 cattle.

\section{Data collection and Analysis}

For this study, a database was prepared with the information obtained from the (WHO, 2013; WAHIS, 2019), of cases reported for suspected neurological disease, which corresponds to rabies. Thus, it was confirmed by laboratory analysis by state official zoosanitary control agencies of Ecuador during the 2012-2018 period. Once the 
Santiago Alexander Guamán-Rivera; Walter Efraín Castro-Guamán; Raúl Lorenzo González-Marcillo; Angela Edith Guerrero-Pincay

information was purified, the events related to the bovine species were worked on. This is due to their importance within the complex existing livestock system as the main economic activity of the population.

Besides, damage caused by vampire rabies transmitted by bats to livestock have economic consequences for cattle producer and communities in this region (e.g., damaged hides, weight loss, decreased milk production, death). Humans (post-exposure prophylaxis, death) also has economic consequences for the cattle producer and the communities of this region.

\section{Statistical Analysis}

Data were entered using Excel 2013 and transferred to the statistical package (SAS 9.4; SAS Inst. Inc., Cary, NC), sorted by month and year, using the descriptive statistics and interquartile values of the cases of rabies presented using dynamic tables. To evaluate the behaviour of rabies in the studied region, the endemic channel was prepared from the monthly frequencies of cases that occurred during 2012-2018. This endemic channel was based on the method of the median and quartiles with raw numbers (Bortman,2007; Bárcenas-reyes et al., 2015). In addition to the data of the bovine population per year plus the events notified and published in the (WAHIS, 2019; WHO, 2013), the prevalence was obtained. Thus, the results were presented in tables whose multiplication factor was 1010 depending on the number of animals considered in the calculations.

\section{RESULTS AND DISCUSSION}

The disorders of the nervous system in cattle include a group of economically important diseases that present viral, bacterial, toxic, circulatory, metabolic, congenital, and neoplastic causes (Terra et al., 2018). Research in the field indicates that rabies virus behavior in vampire populations is similar to that of other infectious agents in other hosts (Lord et al., 1977). Bovine rabies in America Latina is commonly called derriengue, a Spanish word for a fatal paralytic disease (Johnson et al., 2014). The disease has an 
Santiago Alexander Guamán-Rivera; Walter Efraín Castro-Guamán; Raúl Lorenzo González-Marcillo; Angela Edith Guerrero-Pincay

endemic occurrence in the Ecuadorian Amazon, which affects this species most especially (Hidalgo, 2013; Castro et al., 2017). The results obtained from the 2012-2018 data review are shown in Table 1. A total of 44 outbreaks were notified and confirmed by a laboratory (OIE, 2019), by official zoosanitary entities of Ecuador (WHO, 2013). In 2012, the prevalence expressed as a percentage for 10000 cattle was higher $(6.4 \% / 10000$ animals). For the remaining years, they were not homogeneous throughout the study time. Thus, the cases are presented mainly in areas of high tree density such as forest.

\begin{tabular}{cccc}
\hline Year & Outbreaks & Animal Population & Prevalence, \% \\
\hline 2012 & 23 & 35942 & 6.4 \\
2013 & 11 & 35942 & 3.1 \\
2014 & 4 & 35942 & 1.1 \\
2015 & 1 & 49532 & 0.2 \\
2016 & 0 & 49532 & 0.0 \\
2017 & 0 & 56604 & 0.0 \\
2018 & 5 & 56604 & 0.9 \\
\hline
\end{tabular}

Table 1. Prevalence of bovine rabies cases expressed as a percentage per 10000 cattle This decrease in the cases reported could be explained in some way to officially control programs that included raising awareness among producers, training curriculum on the disease, and notifying outbreaks due to suspicion of neurological disease by key actors (farmers, vaccinators, students, civil society in general). This thereby facilitates the attention and subsequent confirmation and reporting of the presence of the disease, which requires additional studies to explain this behavior. However, due to social, economic and environmental characteristics of the region, many farmers, since most outbreaks are 
Santiago Alexander Guamán-Rivera; Walter Efraín Castro-Guamán; Raúl Lorenzo González-Marcillo; Angela Edith Guerrero-Pincay

reported in very distant farms with difficult access roads, fail to highlight the suspicion of neurological diseases in their animals, verbal communication (undocumented). Thus, this is evidenced in the years 2013-2018 by a downward trend in the report of outbreaks due to suspicion of rabies, without ruling out that these, control actions could have helped reduce the outbreaks. Therefore, the epidemiology of rabies deserves increasing attention from government institutions and researchers, which seek to introduce strategies that limited the spread of bovine rabies among wild animals. It also eliminate the virus in these reservoirs, species by species, by establishing coordinated epidemiological nongovernmental, private, and civil society that includes notification procedures, attention, laboratory diagnosis (antigenic and genetic), as well as the realization of integrated studies of catches, ecology, and genetics for the knowledge of the dynamics of rabies in the wild (Fahl et al., 2015).

This is so important because, like the study of (Muñoz, 1990; Korpershoek et al., 2016), our study is based on the information of the outbreaks presented. We also related their occurrence to two conditioning factors: Biological and non-biological. Biological factors include the presence of vampire bats, the existence of adequate shelter for them (Lord et al., 1977), the availability of food sources, and the presence of rabies virus in the area. Nonbiological factors include the type of human productive process and changing patterns in such activities, working and living conditions, access to rabies prophylaxis, and measures being implemented to control bat populations (Contreras, 2017). Biological factors are among the conditions necessary for maintaining the chain of transmission in the wildlife cycle of bat-transmitted rabies. These factors constitute elemental rabies foci. Here, once humans' dwell in the focus area, structural changes triggered by nonbiological or social factors make the diseases emerge.

According to the interquartile levels established from the treated and reported outbreaks (between 0 and 3.5 cases) Figure 1, they were classified as insignificant risk (first quartile). In addition, those who presented one case, as low risk (second quartile), coincided with the median i.e., those who presented 1 to 2 cases. For the medium risk (third quartile), 
Santiago Alexander Guamán-Rivera; Walter Efraín Castro-Guamán; Raúl Lorenzo González-Marcillo; Angela Edith Guerrero-Pincay

those who had more than 3 cases, being on average 1 case according to the interquartile analysis, performed for each month for the period 2012-2018.

The dynamics of presentation throughout the entire study period could be assumed due to annual climatic variations that affect the vector in contrast (Johnson et al., 2014; Seetahal et al., 2019) vampire bats feed preferentially on the blood of cattle that are generally larger than native wildlife prey species. In addition, they are more abundant and tend to remain in the same place for prolonged periods. Once a colony of vampire bats has located a herd of animals, they can return to the same place the following nights.

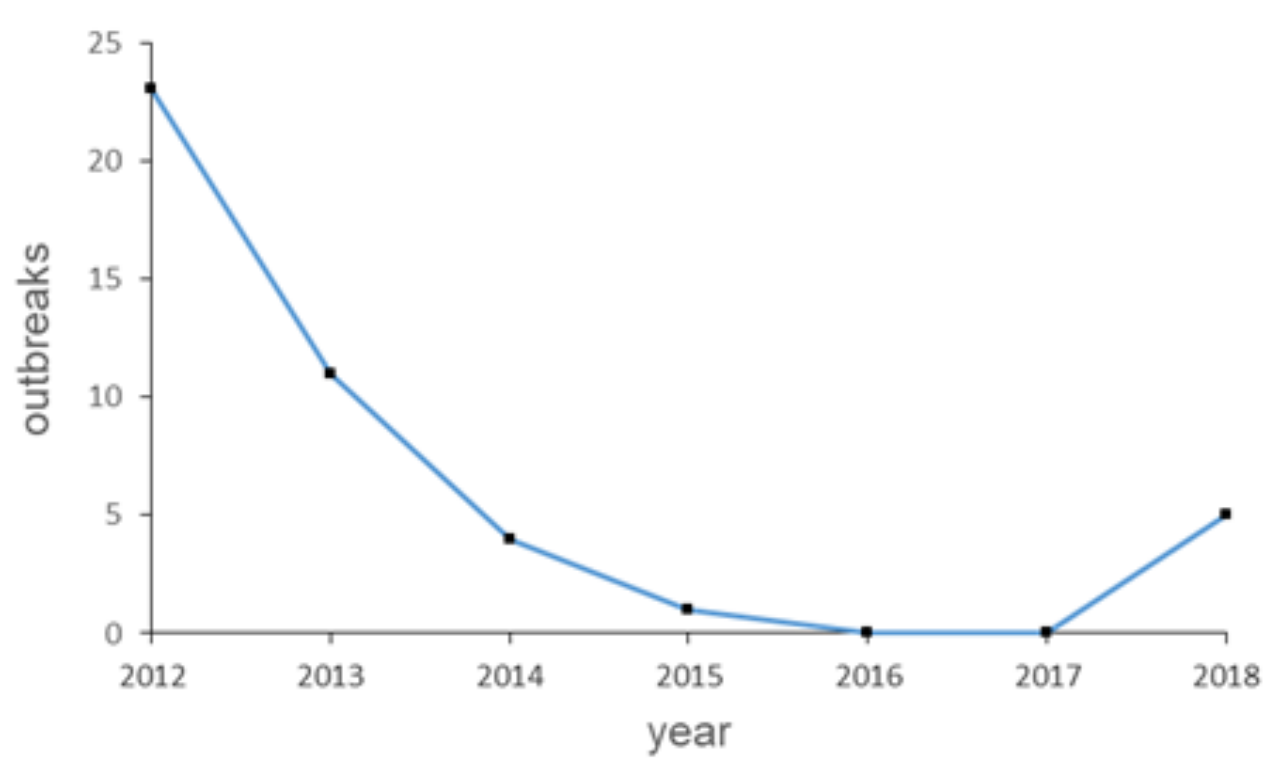

Figure 1. Number of annual bovine rabies outbreaks in Orellana, 2012 to 2018

Unlike the study of (Brito-Hoyos et al., 2013), rabies outbreaks in the province of Orellana occurred throughout the year, without showing seasonality or relationship with the rainfall regime. Figure 2 shows that the vector remains active because it does not hibernate or migrate (Delpietro \& Russo, 1996;Juárez Castillo, 2012; Ripperger et al., 2018). However, something curious is that according to historical data on the climate of region, March and 
Santiago Alexander Guamán-Rivera; Walter Efraín Castro-Guamán; Raúl Lorenzo González-Marcillo; Angela Edith Guerrero-Pincay

April are the months with more rain $\left(229 \mathrm{~mm} ; 27.5^{\circ} \mathrm{C}\right)$. It is the period there is more notifications of the disease. However, in July $\left(77 \mathrm{~mm} ; 26^{\circ} \mathrm{C}\right)$, no events are reported, and this may be due to the slow population recovery in the vampire colony. This is also due to the low reproduction rate 5 months of gestation (the vampire has one baby per year) and the high youth mortality rate (Hernandez et al., 2002). The habitat, which in turn is developed, does not provide comfortable conditions. Our work also suggests that the evolution of rabies, according to the data with which it is available, and its distribution within forested ecosystems in which agricultural activities are gaining ground helps in determining the location vectors of these sources of feeding. Therefore, it is important to control all biological variables that could be included in a deeper study, which allows us to clarify the situation in the area of the equator.

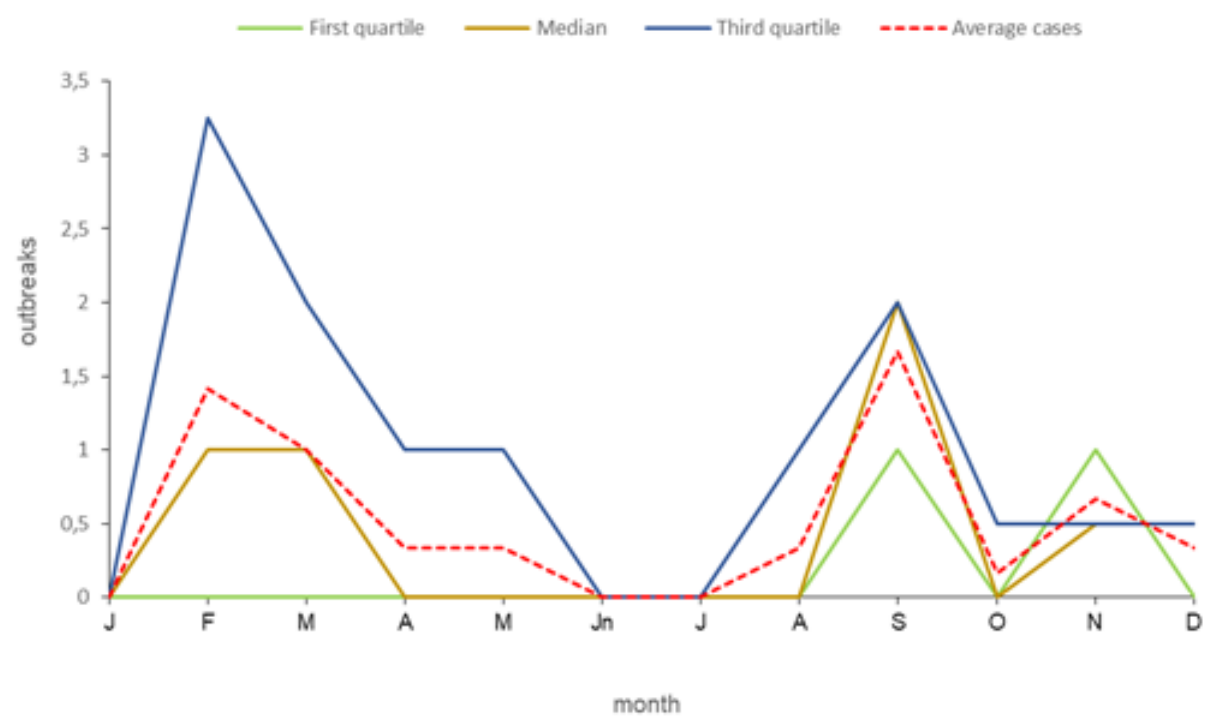

Figure 2. Endemic channels of outbreaks of bovine rabies in Orellana 2012-2018 period 
Santiago Alexander Guamán-Rivera; Walter Efraín Castro-Guamán; Raúl Lorenzo González-Marcillo; Angela Edith Guerrero-Pincay

\section{CONCLUSIONS}

Finally, we can mention two basic questions. First, the decrease and reporting of notifications of health events related to suspected bovine rabies is due to actions of control and application of rigorous immunization protocols, or conjectural characteristics linked to social, environmental, political, and economic factors. Therefore, this first approach allowed us to obtain in a certain way a current photograph of the disease status based on information reported during this period. It also helps us identify, suggest, and propose the articulation of state and non-governmental organizations establishing responsibilities, commitments, and agreements to address the problem of zoonotic and economic repercussions on the population linked to livestock activities.

\section{FINANCING}

Non-monetary

\section{GRATITUDE}

To the Autonomous University of Barcelona, Spain and the Escuela Superior Politécnica de Chimborazo, Ecuador; for motivating and stimulating research

\section{REFERENCES CONSULTED}

Anderson, A., Shwiff, S. ,S., \& Shwiff, S. , A. (2014). Economic Impact of the Potential Spread of Vampire Bats into South Texas. Proceedings of the Vertebrate Pest Conference, 26. https://doi.org/10.5070/v42611047

Bárcenas-reyes, I., Loza-rubio, E., Zendejas-martínez, H., \& Luna-soria, H. (2015). Epidemiological behavior of bovine paralytic rabies in the central region of Mexico , 2001 - 2013. Rev Panam Salud Publica, 38(5), 396-402.

Bellido, J. B. (2016). Introduction to epidemiological studies. Retrieved from https://n9.cl/53qha 
Santiago Alexander Guamán-Rivera; Walter Efraín Castro-Guamán; Raúl Lorenzo González-Marcillo; Angela Edith Guerrero-Pincay

Belotto, A., Leanes, L. F., Schneider, M. C., Tamayo, H., \& Correa, E. (2005). Overview of rabies in the Americas. Virus Research, 111(1), 5-12. https://doi.org/10.1016/..virusres.2005.03.006

Bortman, M. (2007). Development of endemic corridors or channels using spreadsheets. Pan American Journal of Public Health, 5(1), 1-8. https://doi.org/10.1590/s1020$\underline{49891999000100001}$

Braga, G. B., Grisi-Filho, J. H. H., Leite, B. M., de Sena, E. F., \& Dias, R. A. (2014). Predictive qualitative risk model of bovine rabies occurrence in Brazil. Preventive Veterinary Medicine, https://doi.org/10.1016/j.prevetmed.2013.12.011

Brito-Hoyos, D. M., Sierra, E. B., \& Álvarez, R. V. (2013). Geographic distribution of wild rabies risk and assessment of factors associated with its incidence in Colombia, 1982-2010. Pan American Journal of Public Health, 33(1), 08-14. https://doi.org/10.1590/s1020-49892013000100002

Calderon, A., Guzman, C., Salazar-Bravo, J., Figueiredo, L. T., \& Mattar, S. (2018). Viral Zoonoses That Fly with Bats: A Review. MANTER: Journal of Parasite Biodiversity. https://doi.org/10.13014/k2bg2kwf

Castro, M. M. de, Gonçalves, W. G., Teixeira, S. A. M. V., Fialho, M. do C. Q., Santos, F. C., Oliveira, J. M., ... Machado-Neves, M. (2017). Ultrastructure and morphometric features of epididymal epithelium in Desmodus rotundus. Micron, 102(August), 3543. https://doi.org/10.1016/j.micron.2017.08.006

Cerda, J., Vera, C., \& Rada, G. (2013). [Odds ratio: theoretical and practical issues]. Revista Médica de Chile, 141(10), 1329-1335. https://doi.org/10.4067/S0034$\underline{98872013001000014}$

Contreras, Z. L. (2017). Spatial and temporal analysis of bovine rabies of wild origin in Colombia (2005-2014 ). Universidad Autónoma De Barcelona, Facultad De Veterinaria.

Delprieto, H. A., \& Russo, R. G. (1996). Economic and epidemiological aspects of vampire attack and paralytic rabies in Argentina and analysis of proposals for their control. Revue Scientifique et Technique de I'OIE, 15(3), 971-984. https://doi.org/10.20506/rst.15.3.964 
Santiago Alexander Guamán-Rivera; Walter Efraín Castro-Guamán; Raúl Lorenzo González-Marcillo; Angela Edith Guerrero-Pincay

Fahl, W. O., Achkar, S. M., Mori, E., Asano, K. M., lamamoto, K., Scheffer, K. C., \& Garcia, A. I. E. (2015). Rabies transmitted by bats in Brazil. Acta Biologica Colombiana, 20(3), 21-35. https://doi.org/10.15446/abc.v20n3.45481

GADPO. (2015). Development and Land Management Plan of the Province of Orellana.

Heinemann, M. B., Fernandes-Matioli, F. M. C., Cortez, A., Soares, R. M., Sakamoto, S. M., Bernardi, F., Richtzenhain, L. J. (2002). Genealogical analyses of rabies virus strains from Brazil based on $\mathrm{N}$ gene alleles. Epidemiology and Infection, 128(3), 503-511. https://doi.org/10.1017/S095026880200688X

Hernandez, C. S., Alvaraz, M. de L. R., Oviedo, A. F., Estrada, C. G., \& Cruz, M. V. S. (2002). Desmodus Rotundus.Pdf. Natural History of the Chamela.

Hidalgo L.R. (2013). Epidemiological situation of urban and wild rabies in Ecuador. National Institute of Hygiene and Tropical Medicine Leopoldo Izquieta Pèrez, 53(9), 1689-1699. https://doi.org/10.1017/CBO9781107415324.004

INAMHI. (2016). Meteorological Bulletin N492 month: February 2016. Retrieved from https://n9.cl/9sxd

INEC. (2010). Seventh Population Census and Sixth Housing Census. Inec. Retrieved from https://n9.cl/ekwi

Inzunza, J. (2007). Chapter 14. Earth's Climates. In Descriptive Meteorology (p. 31).

Johnson, N., Aréchiga-Ceballos, N., \& Aguilar-Setien, A. (2014). Vampire bat rabies: Ecology, epidemiology and control. Viruses, 6(5), 1911-1928. https://doi.org/10.3390/v6051911

Juárez Castillo, L. G. (2012). Population dynamics of the vampire bat Demodus rotundus (Chiroptera: Phyllostomidae) in the Barranca de Metztitlan Biosphere Reserve, Hidalgo, Mexico. Universidad Autónoma Del Estado de Hidalgo, 163.

King, A. A., \& Turner, G. S. (1993). Rabies: A Review. Journal of Comparative Pathology, 108(1), 1-39. https://doi.org/10.1016/S0021-9975(08)80224-1

Korpershoek, H., Beijer, C., Spithoff, M., \& Naaijer, H. (2016). Overgangen en aansluitingen in het onderwijs, 25(16), 260-269. Retrieved from https://n9.cl/i0can 
Santiago Alexander Guamán-Rivera; Walter Efraín Castro-Guamán; Raúl Lorenzo González-Marcillo; Angela Edith Guerrero-Pincay

Lee, D. N., Papeş, M., \& van Den Bussche, R. A. (2012). Present and potential future distribution of common Vampire bats in the Americas and the associated risk to cattle. PLoS ONE, 7(8), 1-9. https://doi.org/10.1371/journal.pone.0042466

Lord, D. R. D., Fuenzalida, E., Delpietro, H., Larghi, O. P., Díaz, M. De, \& Luis, S. (1977). Observations on Vampire Rabies, 82(6), 498-505.

MAGAP. (2019). Situational Bulletin. Quito-Ecuador. Retrieved from https://n9.cl/ozd3

Marcillo, R. L. G. (2018). Investigation Of The Attitudes Of Cattlemen In The Implementation Of Silvopastoral Systems In The Canton Joya De Los Sachas. $\begin{array}{llll}\text { European Scientific Journal, } & \text { ESJ, 14(27), }\end{array}$ https://doi.org/10.19044/esj.2018.v14n27p357

Mello, A. K. M., Brumatti, R. C., Neves, D. A., Alcântara, L. O. B., Araújo, F. S., Gaspar, A. O., \& Lemos, R. A. A. (2019). Bovine rabies: economic loss and its mitigation through antirabies vaccination. Pesquisa Veterinária Brasileira, 39(3), 179-185. https://doi.org/10.1590/1678-5150-pvb-6201

Muñoz, M. F. (1990). Rabies: a zoonosis of interest in Andalucia. Anales de La Real Academia de Ciencias Veterinarias de Andalucía Oriental, 2, 3-20.

National Assembly of Ecuador. (2017). Organic Law on Agricultural Health. Official State Gazette, Registro O (3 de julio), 1-24.

OIE. (2019). The World Organisation for Animal Health. Retrieved from https://n9.cl/ucn4z

Ortiz-Prado, E., Ponce-Zea, J., Ramirez, D., Stewart-lbarra, A. M., Armijos, L., Yockteng, J., \& Cardenas, W. B. (2015). Rabies Epidemiology and Control in Ecuador. Global Journal of Health Science, 8(3), 113. https://doi.org/10.5539/gihs.v8n3p113

Patel, K., \& Saxena, D. (2019). Self-reported selected zoonotic diseases among animal handlers in Urban Ahmedabad, India. Veterinary World, 12(1), 176-182. https://doi.org/10.14202/vetworld.2019.176-182

Ríos, S., Benítez, D., \& Soria, S. (2016). Territorial food chains. Tensions and learning from the dairy sector in the Ecuadorian Amazon. Economics Readings, (84). https://doi.org/10.17533/udea.le.n84a06 
Santiago Alexander Guamán-Rivera; Walter Efraín Castro-Guamán; Raúl Lorenzo González-Marcillo; Angela Edith Guerrero-Pincay

Ripperger, S., Guenther, L., Wieser, H., Duda, N., Hierold, M., Cassens, B., Mayer, F. (2018). Proximity sensors reveal social information transfer in maternity colonies of Greater noctule bats. BioRxiv, 421974. https://doi.org/10.1101/421974

Rocha, S. M., de Oliveira, S. V., Heinemann, M. B., \& Gonçalves, V. S. P. (2017). Epidemiological Profile of Wild Rabies in Brazil (2002-2012). Transboundary and Emerging Diseases, 64(2), 624-633. https://doi.org/10.1111/tbed.12428

Rupprecht, C. E., Hanlon, C. A., \& Hemachudha, T. (2002). Rabies re-examined. Lancet Infectious Diseases, 2(June), 327-343. https://doi.org/10.1016/S14733099(02)00287-6

San Sebastián, M., Játiva, R., \& Goicolea, I. (2007). Epidemiology of malaria in the Amazon basin of Ecuador. Revista Panamericana de Salud Pública, 7(1), 24-28. https://doi.org/10.1590/s1020-49892000000100004

Seetahal, J. F. R., Sanchez-Vazquez, M. J., Vokaty, A., Carrington, C. V. F., Mahabir, R., Adesiyun, A. A., \& Rupprecht, C. E. (2019). Of bats and livestock: The epidemiology of rabies in Trinidad, West Indies. Veterinary Microbiology, 228(November 2018), 93-100. https://doi.org/10.1016/j.vetmic.2018.11.020

Terra, J. P., Blume, G. R., Rabelo, R. E., Medeiros, J. T., Rocha, C. G. N., Chagas, I. N., ... Sant'Ana, F. J. F. de. (2018). Neurological diseases of cattle in the state of Goiás, Brazil (2010-2017). Pesquisa Veterinária Brasileira, 38(9), 1752-1760. https://doi.org/10.1590/1678-5150-pvb-5768

Valderrama, J., García, I., Figueroa, G., Rico, E., Sanabria, J., Rocha, N., Páez, A. (2006). Outbreaks of human rabies transmitted by vampires in the municipalities of Bajo and Alto Baudó, Chocó department, Colombia 20. Biomedical, 26(January 2005), 387-396.

Veloso, R. D., Aerts, D. R. G. de C., Fetzer, L. O., Anjos, C. B. dos, \& Sangiovanni, J. C. (2011). Epidemiological profile of human anti-rabies care in Porto Alegre, RS, Brazil. Science \& Collective Health, 16(12), 4875-4884. https://doi.org/10.1590/s1413-81232011001300036

WAHIS. (2019). Global Animal Health Information System Database. Retrieved from https://n9.cl/6jxpd

WHO. (2013). WHO Expert Consultation on Rabies. Second report. World Health Organization Technical Report Series, (982). 
Revista Arbitrada Interdisciplinaria KOINONIA

Año V. Vol V. Nº9. Enero - Junio 2020

Hecho el depósito de Ley: FA2016000010

ISSN: 2542-3088

FUNDACIÓN KOINONIA (F.K). Santa Ana de Coro. Venezuela.

Santiago Alexander Guamán-Rivera; Walter Efraín Castro-Guamán; Raúl Lorenzo González-Marcillo; Angela Edith Guerrero-Pincay

(02020 por los autores. Este artículo es de acceso abierto y distribuido según los términos y condiciones de la licencia Creative Commons Atribución-NoComercial-Compartirlgual 4.0 Internacional (CC BY-NC-SA 4.0) (https://creativecommons.org/licenses/by-nc-sa/4.0/). 